\title{
ANALISIS PERILAKU MASYARAKAT PERKOTAAN PADA RUANG PUBLIK DI PERUMAHAN KOTA DENPASAR
}

\author{
A.A Gede Trisna Gamana Pratama \\ Program Studi Teknik Industri, Fakultas Teknik, Universitas Mahendradatta \\ Jl. Ken Arok No.12, Peguyangan, Denpasar, Bali 80115 \\ Email: trisnagamana@gmail.com
}

\begin{abstract}
Abstrak - Perkembangan Kota Denpasar sebagai Ibu Kota Provinsi Bali dan sekaligus sebagai Pusat Pertumbuhan Bali, mengakibatkan pertumbuhan dan perkembangan kota menjadi sangat pesat. Kendati Pemerintah Kota Denpasar telah berusaha mengarahkan dan menata lingkungan melalui penataan ruang, namum arah perkembangan dan pertumbuhan bangunan-bangunan belum terarah dan berkembang sangat sporadis ke arah seluruh bagian kota. Penelitian ini menggunakan penelitian kualitatif deskriptif dengan pendekatan rasionalistik berdasarkan kenyataan dilapangan dengan data primer diperoleh dari hasil observasi, dokumentasi berupa image perilaku masyrakat terhadap ruang publik di perumahan kota. Hasil penelitian menunjukkan pemanfaatan ruang publik sebagai area private pada lingkungan perumahan didominasi karena faktor terbatasnya lahan rumah terhadap kebutuhan pemilik rumah seperti memiliki kendaraan melebihi kapasitas garase rumah.
\end{abstract}

Kata kunci :Ruang Publik, Perumahan Kota, Kota Denpasar

\begin{abstract}
The development of Denpasar City as the Capital of the Province of Bali and at the same time as the Center for Bali Growth, resulted the growth and development of the city become very rapid. Although the Denpasar City Government has tried to direct and organize the environment through spatial planning, however the direction of development and the growth of buildings has not been directed yet and is developing very sporadically towards all parts of the city. This study uses descriptive qualitative research with a rationalistic approach based on reality in the field with primary data obtained from observations, documentation in the form of images of community behavior towards public spaces in city housing. The results showed that the use of public space as a private area in the housing environment is dominated by factors due to the limited land of the house to the needs of home owners such as having vehicle that exceeds the garage capacity of the house.
\end{abstract}

Kata kunci : Public Spaces, City Housing, Denpasar City

\section{PENDAHULUAN}

Kota Denpasar terletak di tengah-tengah Pulau Bali, selain merupakan Ibu Kota Provinsi, sekaligus menjadi pusat pemerintahan, pendidikan, perekonomian pariwisata, dan pusatpusat kegiatan lainnya. Letak tersebut sangat strategis, baik dari segi ekonomi maupun kepariwisataan karena merupakan titik sentral berbagai kegiatan, sekaligus sebagai penghubung antara kabupaten lainnya. Perkembangan Kota Denpasar sebagai lbu Kota Provinsi Bali dan sekaligus sebagai Pusat Pertumbuhan Bali, mengakibatkan pertumbuhan dan perkembangan kota menjadi sangat pesat. Kendati Pemerintah Kota Denpasar telah berusaha mengarahkan dan menata lingkungan melalui penataan ruang, namum arah perkembangan dan pertumbuhan bangunanbangunan belum terarah dan berkembang sangat sporadis ke arah seluruh bagian kota.

Proses pembangunan perkotaan atau daerah tidak lepas dari perencanaan, karena perencanaan merupakan dasar dari pembangunan suatu wilayah. Tanpa perencanaan proses pembangunan tidak akan berjalan dengan lancar dan sesuai dengan yang diharapkan oleh pemerintah maupun 
masyarakat. Perencanaan tata ruang adalah solusi bagi permasalahan pembangunan wilayah, dalam hal perbedaan tingkat pertumbuhan dan perkembangan antar wilayah serta adanya perbedaan tingkat pendapatan serta kemakmuran. Kesenjangan yang biasanya tajam antara kota besar sebagai pusat pendidikan, perdagangan, pelayanan kesehatan, administrasi pemerintah (sosial ekonomi) dengan wilayah lain di sekitarnya (Rondinelli, 1985).

Peningkatan jumlah penduduk di perkotaan menimbulkan peningkatan kebutuhan perumahan, yang berakibat juga pada harga tanah di perkotaan yang semakin tinggi. Selama ini usaha pemerintah dalam memenuhi kebutuhan peru- mahan bagi masyarakat perkotaan khususnya masyarakat menengah ke bawah adalah pembangunan perumahan sederhana. Berdasarkan survey pembangunan perumahan sederhana ini menghadapi beberapa permasalahan antara lain semakin meningkatnya harga tanah, kualitas bangunan berada di bawah standar, penyediaan sarana dan prasarana kurang seimbang dengan kebutuhan, Sehingga perlu adanya penjelasan lebih lanjut mengenai pengelolaan infrastruktur perkotaan khususnya di Kawasan Perumahan.

\section{RUMUSAN MASALAH}

1. Bagaimana gambaran umum dalam konteks studi kasus yang diambil mengenai pengelolaan infrastruktur perkotaan khususnya di Kawasan Perumahan ?

2.Bagaimana pemahaman mengenai pengelolaan infrastruktur perkotaan khususnya di Kawasan Perumahan?

\section{TUJUAN}

1. Mengidentifikasi gambaran umum dalam konteks studi kasus yang diambil mengenai pengelolaan infrastruktur perkotaan khususnya di Kawasan Perumahan Kota

2.Mengkaji pemahaman mengenai pengelolaan infrastruktur perkotaan khususnya di Kawasan Perumahan Kota

\section{METODOLOGI PENELITIAN}

Pendekatan dilakukan melalui penelitian kualitatif deskriptif dengan pendekatan rasionalistik berdasarkan kenyataan dilapangan yang menjadi focus penelitian dan kemudian ditarik kesimpulan berupa pemahaman umum tentang kenyatan-kenyatan dilapangan dengan data primer diperoleh dari hasil observasi, dokumentasi langsung berupa image analais perilaku masyarakat terhadap ruang publik pada perrmukiman kota. Dalam memecahkan masalah penelitian ini, maka mengkaji mengenai: pemanfaatan ruang public dan analisa perilaku manusia terhadap ruang publik

\section{PEMBAHASAN}

Secara fisik perumahan merupakan sebuah lingkungan yang terdiri dari kumpulan unit-unit rumah tinggal dimana dimungkinkan terjadinya interaksi sosial diantara penghuninya, serta dilengkapi prasarana sosial, ekonomi, budaya, dan pelayanan yang merupakan subsistem dari kota secara keseluruhan. Lingkungan ini biasanya mempunyai aturanaturan, kebiasaan-kebiasaan serta sistem nilai yang berlaku bagi warganya. Sedangkan, Dalam Undang-Undang Nomor 4 tahun 1992 tentang perumahan dan permukiman, perumahan diartikan sebagai kelompok rumah yang berfungsi sebagai lingkungan tempat tinggal atau lingkungan hunian yang dilengkapi dengan sarana dan prasarana.

Pada prinsipnya program pembangunan perumahan dan permukiman bertujuan untuk meningkatkan kualitas kehidupan keluarga dan masyarakat serta meningkatkan kemandirian, kesetiakawanan sosial masyarakat.Program ini dibagi menjadi dua kegiatan yaitu pembangunan perumahan dan permukiman di perkotaan, dan pembangunan perumahan dan permukiman di pedesaan.

Stephen Carr, dkk (1992) melihat ruang terbuka publik sebagai ruang milik bersama, tempat masyarakat melakukan aktivitas fungsional dan ritualnya dalam suatu ikatan komunitas, baik kehidupan sehari-hari maupun dalam perayaan berkala yang telah ditetapkan sebagai sesuatu yang terbuka, tempat masyarakat melakukan aktivitas pribadi dan kelompok. Aktivitas sosial dapat diartikan sebagai kegiatan yang membutuhkan kehadiran orang lain (Zhang dan Lawson, 2009). Kegiatan 
ini dapat berupa perbincangan santai di pinggir jalan, bertatap muka maupun kegiatan anakanak bermain di taman kota. Penanganan ruang publik yang kreatif dapat mendukung terbentuknya aktivitas sosial antara orangorang yang tidak saling mengenalsebelumnya. Adanya pementasan kesenian di taman kota dapat menjadi contoh. Kegiatan-kegiatan kreatif yang diselenggarakan di ruang-ruang terbuka (baik yang bertujuan komersial maupun non-komersial) dapat mendorong warga untuk saling berbincang atau sekedar saling mengomentari kegiatan kreatif tersebut, demikian juga dengan pemasangan karya seni instalasi di ruang publik.

\section{STUDI KASUS}

Lokasi Perumahan Puri Taman dengan jumlah \pm 100 unit, berlokasi di Kota Denpasar tepatnya di Kecamatan Denpasar Barat dan berada di wilayah Padang sambian Kelod di Jalan Gn. Soputan.berjarak $\pm 8,9 \mathrm{~km}$ atau \pm 20 menit perjalanan menuju pusat Kota Denpasar. Letak Perumahan Nuansa Sandat Biaung dalam Kota Denpasar dapat dilihat pada gambar 1 di bawah ini.
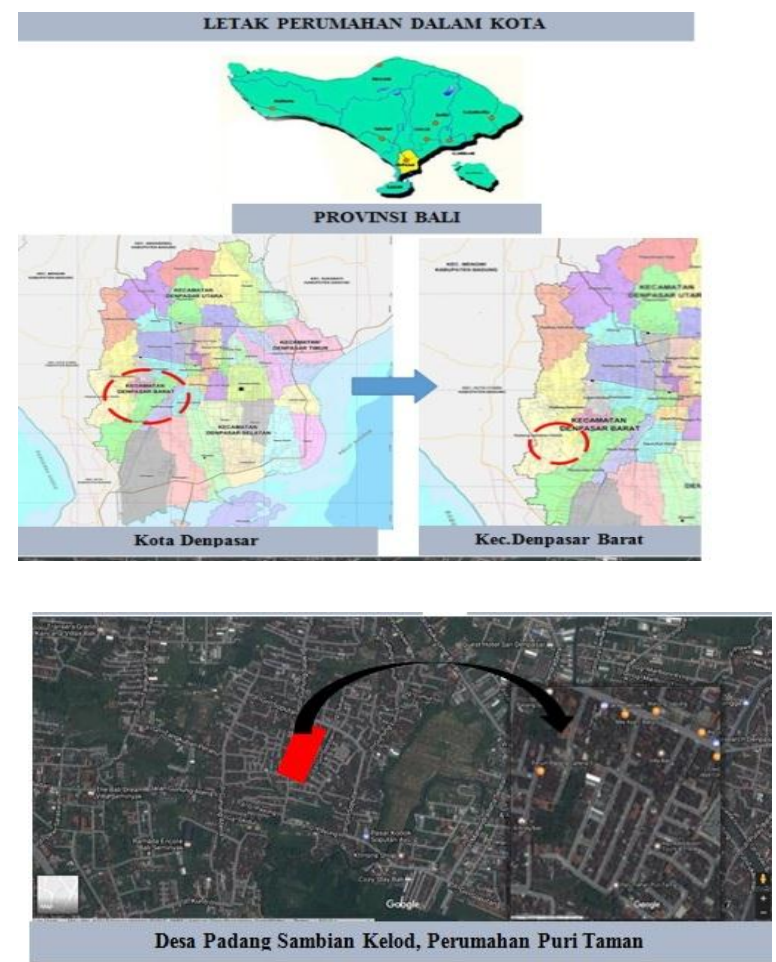

Gambar 1. Letak Perumahan
Masterplan pada Perumahan Puri Taman ini terbagi menjadi 5 zona yaitu : (a) zona perumukiman, (b) zona lapangan serbaguna, (c) zona balai banjar, (d) zona tempat penyewaan parkir dan (e) zona lahan kosong, untuk lebih jelas mengenai pembagian masterplan yang terdapat di Perumahan Puri Taman di Jl. Gn. Soputan, Padang Sambian Kelod ini antara lain:

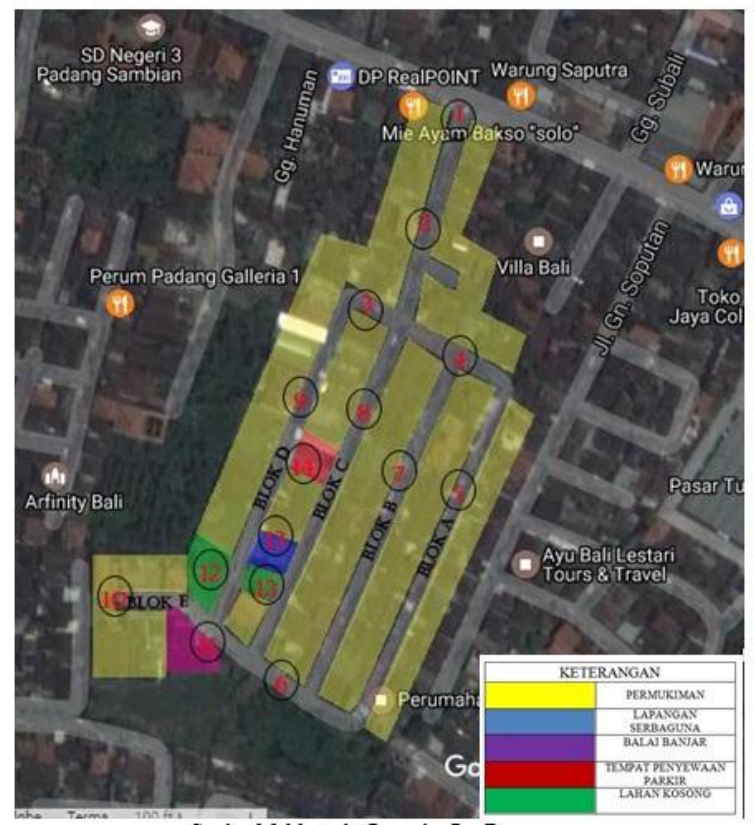

Gambar 2. Masterplan Perumahan

Pada gambar 3 ini menjelaskan mengenai keterangan gambar-gambar fasilitas publik yang ada pada perumahan pada studi kasus ini meliputi balai banjar, lapangan voli, penyewaan lahan parkir, lahan kosong dll.
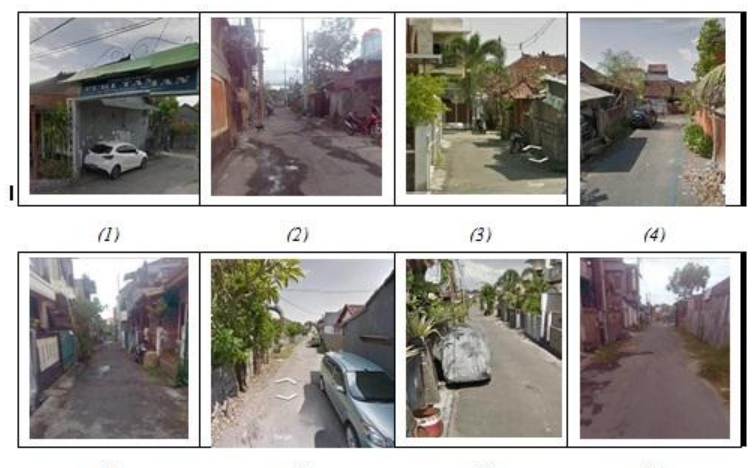

(5)

(6) 

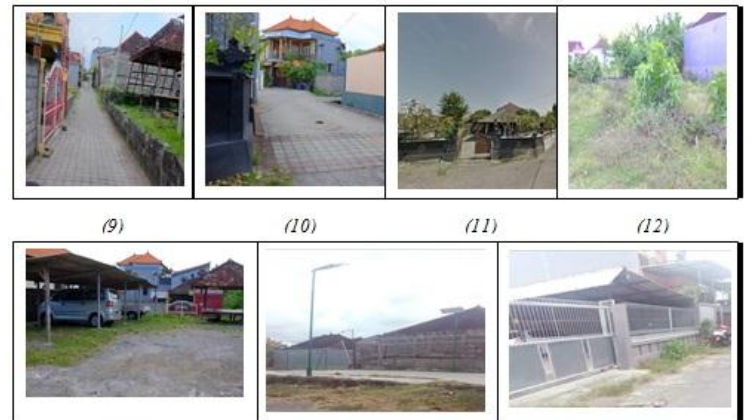

(12)

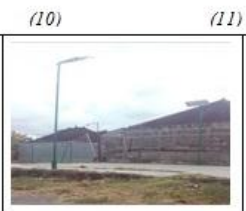

(13)

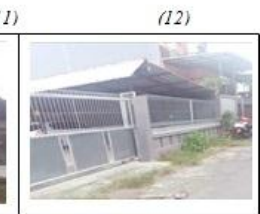

(14)

Gambar 3. Ket.Masterplan Perumahan

Gambar denah, tampak dan potongan ruang publik jalannya terbagi tiga yaitu : (a) lebar jalan 2 meter yang terdapat di Blok A,D, dan (b) lebar jalan 3 meter yang terdapat pada Blok $\mathrm{B}$,dan $\mathrm{E}$, (c) lebar 4 meter pada Blok $\mathrm{C}$ dan jalan Tipe rumah 130/150 rata-rata berada di Blok $D$ dan sebagian di Blok $B$, sedangkan untuk tipe rumah 100/150 rata-rata berada di Blok $A$ dan $E$, dan untu tipe rumah $80 / 100$ berda di Blok $A$, yang terdapat di Perumahan Puri

Taman di Jl. Gn. Soputan, Padang Sambian Kelod ini, antara lain:

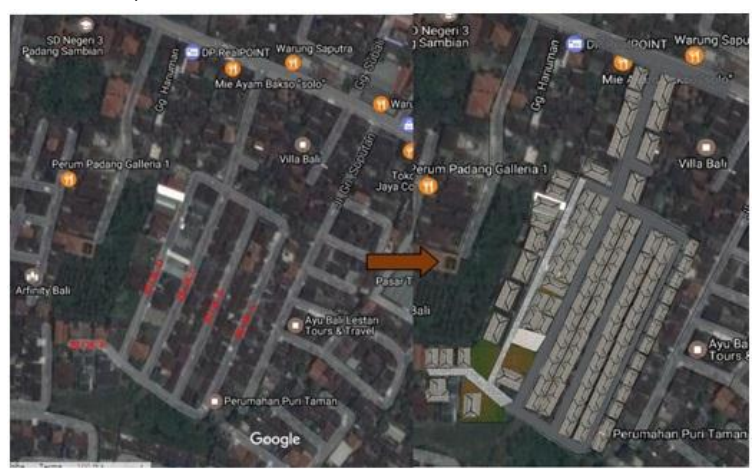

Gambar 4. Siteplan Perumahan

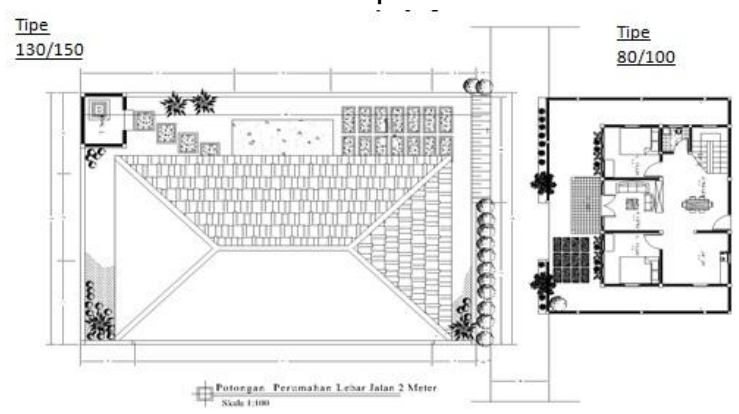

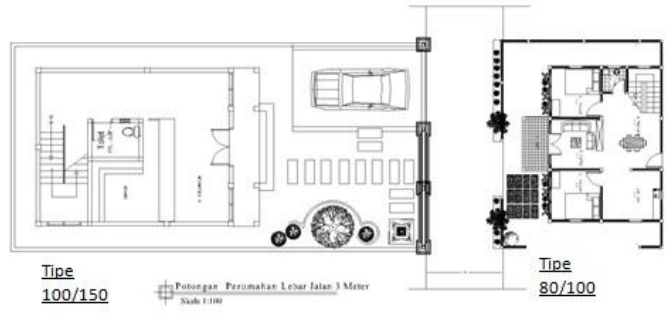

Gambar 5. Denah Perumahan
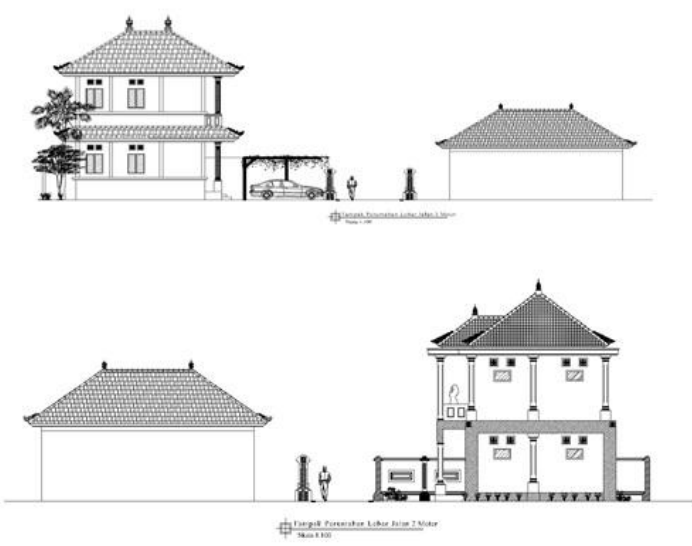

Gambar 6. Tampak Perumahan
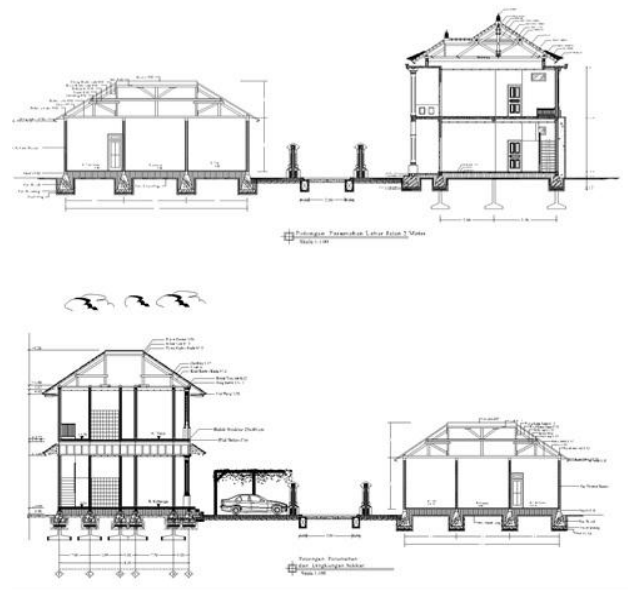

Gambar 7. Potongan Perumahan

Jenis ruang publik yang terdapat pada perumahan Puri Taman ini, antara lain : (a) Jalan lingkungan perumahan, (b) Balai banjar, (c) Lapangan Olahraga, (d) Tempat penyewaan garase, (e) Lahan kosong yang digunakan sebagai alternatif parkir sementara / umum. Perlengkapan jalan yang terdapat pada Perumahan Puri Taman ini, anatara lain : (a) Pada jalan lingkungan perumahan ini dimana pencahayaan lampu jalan masih kurang, titik 
lampu penerangan jalan hanya ada di area ruang publik Bale Banjar, Penyeewaan Parkir dan lapngan Olahraga, sedangkan untuk saluran got pada jalan lingkungan Blok B,C, dan jalan masuk perumahan dan jalan transisi blok depan dan belakang sudah ada saluran got namun keadannya ditutup dengan plat beton agar mampu menambah lebar jalan dan difungsikan sebagai fungsi lain seperti parkir motor dan mobil sehingga menyulitkan dalam hal perawatan dan pengecekan got jika ada yang tersumbat, namun terdapat juga saluran got yang tetap dibiarkan tanpa ditutupi dengan plat beton seperti pada jalan lingkungan Blok $A, D$, dan $E$.

Dimensi ruang publik di perumahan Puri Taman ini , antara lain : (a) pada jalan lingkungan perumahan terdiri dari 3 dimensi yaitu pada jalan masuk lingkungan perumahan dengan lebar jalan 3 meter dengan penyelesaian permukaan berupa jalan aspal, pada jalan transisi depan blok perumahan dengan lebar jalan 3 meter dengan penyelesaian permukaan berupa aspal, jalan lingkungan lingkungan Blok $A$ dengan lebar jalan 2 meter dengan penyelesaian permukaan jalan berupa aspal, jalan lingkungan Blok B dengan lebar jalan 3 meter dengan penyelesaian permukaan jalan berupa aspal, jalan lingkungan Blok $C$ dengan lebar jalan 4 meter dengan penyelesaian permukaan jalan berupa aspal, jalan lingkungan Blok D dengan lebar jalan 2 meter dengan penyelesaian permukaan jalan berupa paving, dan jalan lingkungan Blok $E$ dengan lebar jalan 3 meter dengan penyelesaian permukaan berupa paving. (b) Dimensi ruang publik Balai Banjar dengan ukuran luas lahan area sekitar 2 are, (c) Dimensi ruang publik Lapangan Olahraga dengan luas lahan area sekitar 1 are, (d) Dimensi tempat penyewaan garase memiliki luas area sekitar 2 are, (e) Dimensi lahan kosong yang digunakan sebagai alternative tempat parkir sementara / umum memiliki

luas lahan sekitar 1 are.

Berdasarkan penjelasan gambaran umum ruang publik diatas yang terdapat di perumahan Puri taman ini untuk lebih jelas akan ditampilkan dalam bentuk dokumentasi foto kondisi fisik di Perumahan Puri Taman pada gambar 2.4. di bawah ini.

Kondisi Ruang Publik di Perumahan Puri
Taman,
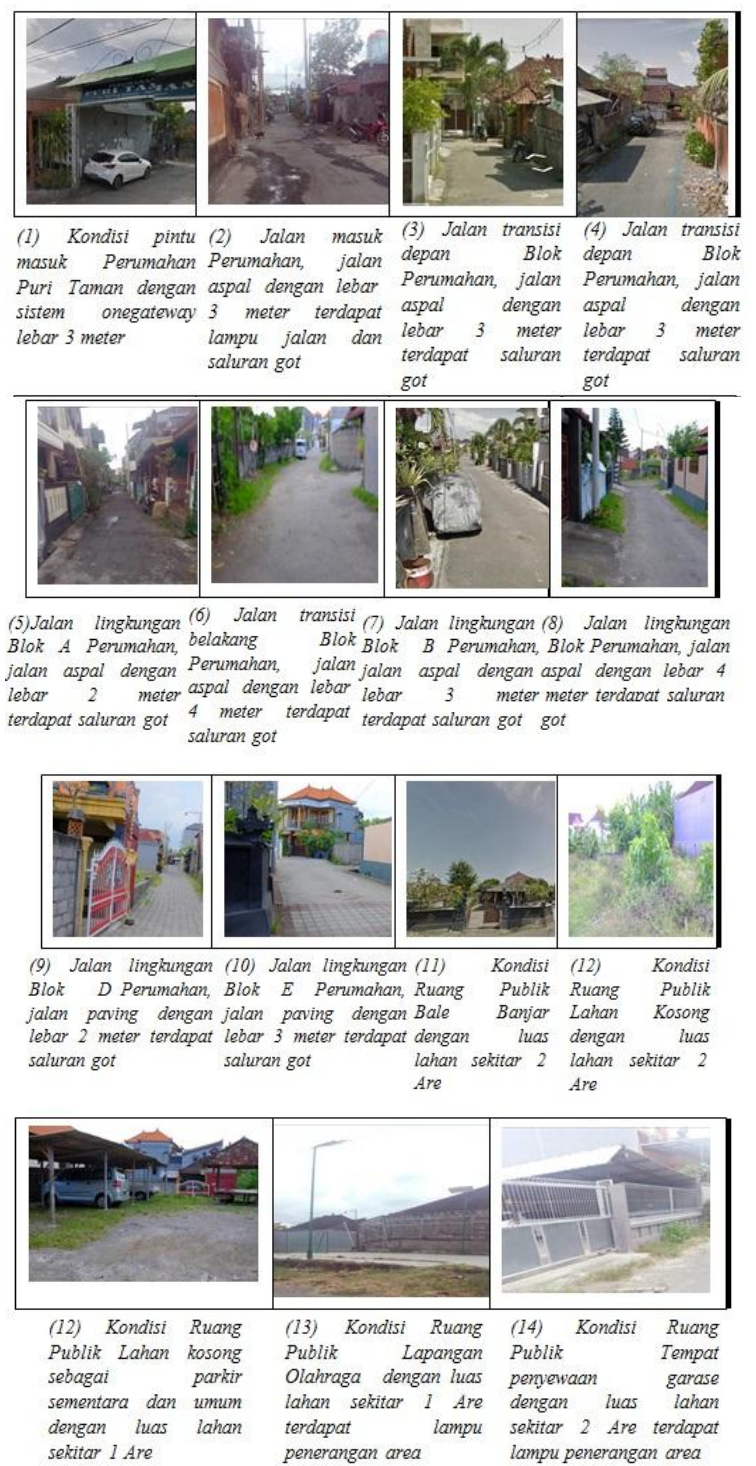

Gambar 8. Kondisi Fisik Perumahan

\section{Pemanfaatan Ruang Publik}

Pemanfaatan Ruang Publik yang terdapat pada perumahan Puri taman ini terdiri dari (a) Jalan lingkungan perumahan sebagai sarana aksesbilitas masyarakat pada perumahan dan sewaktu-waktu digunakan sebagai tempat jika ada acara tertentu, (b) Balai banjar digunakan sebagai saran rapat dan cara pementasan bagi lingkungan perumahan, (c) Lapangan Olahraga digunakan sebagai sarana berekreasi dan berolahraga oleh masyarakat lingkungan perumahan, (d) Tempat penyewaan garase digunakan digunakan sebagai sarana sewa garase kendaraan, (e) 
Lahan kosong yang digunakan sebagai alternatif parkir sementara / umum. Namun selain dari pemanfaatan tersebut ruang publik pada perumahan ini memiliki fungsi lain seperti pada jalan lingkungan perumahan yang digunakan selain sarana aksesbilitas digunakan sebagai parkir kendaraan , jemur pakaian, sebagai menaruh tanaman, dan kandang ayam.

Pengelolaan pemanfaatan ruang publik seperti jalan yang rusak atau ada lubang diperbaikinya dengan cara masyarakat yang berada di lingkungan blok tersebut menyumbangkan secara swadaya demi perbaikan jalan tersebut, sedangkan pengelolaan tempat sewa parkir melalui pengelolaan individu selaku pemilik lahan dengan ijin dari ketua RT, pengelolaan bale banjar dan lapangan olahraga melalui sumbangan secara swadaya melalui seluruh masyarakat di lingkungan perumahan Puri Taman ini jika mengalami kerusakan atau perbaikan. Berdasarkan penjelasan pemanfaatan ruang publik diatas yang terdapat di perumahan Puri taman ini untuk lebih jelas akan ditampilkan dalam bentuk dokumentasi foto kondisi fisik pemanfaatan di Perumahan Puri Taman pada gambar 9.di bawah ini.

a. Pemanfaatan jalan lingkungan sebagai tempat parkir kendaraan (pagimalam)

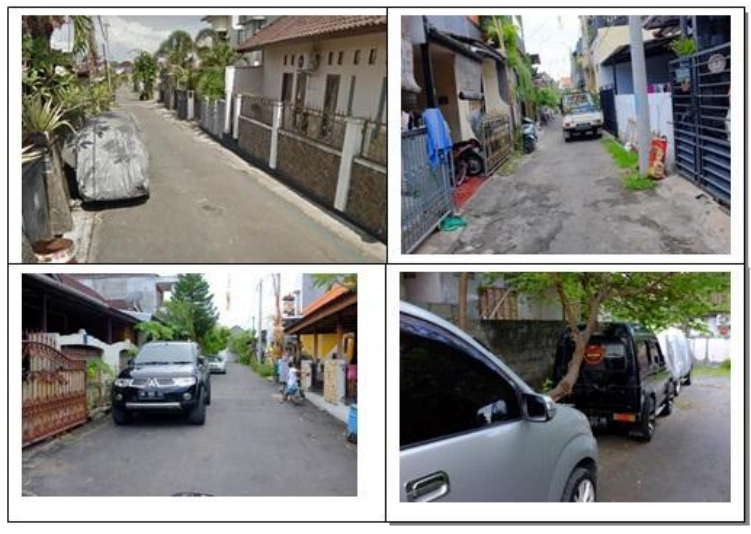

b. Pemanfaatan jalan lingkungan sebagai tempat menjemur pakaian (pagi-siang)

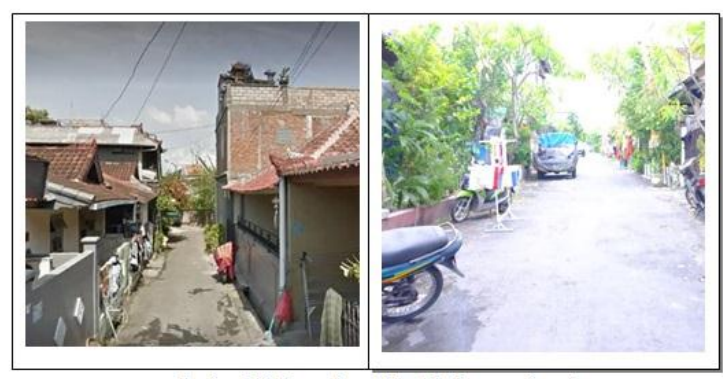

c. Pemanfaatan jalan lingkungan sebagai tempat menaruh kandang ayam (pagi-siang)

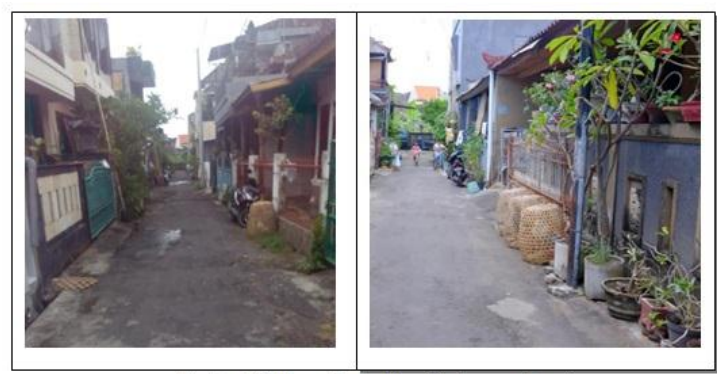

Gambar 9. Pemanfaatan Publik

Analisis perilaku masyarakat pada ruang publik Perumahan Puri Taman terdiri dari pemanfaatan ruang publik sebagai tempat parkir kendaraan, jemur pakaian dan sebagai tempat menaruh kandang ayam. Untuk lebih jelas dpat terlihat dari Gambar ini.

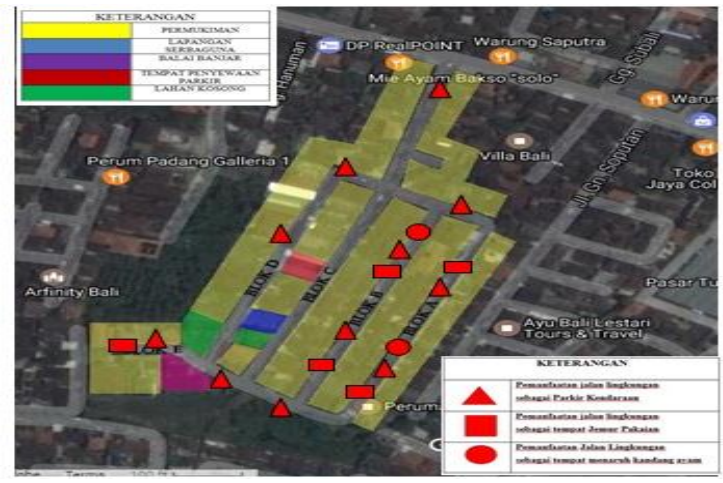

\section{Analisis Pemanfaatan TerhadapJml Jam Penggunaan/Hari}

Berdasarkanjumlahjampenggunaan/haridiPe rumahanPuriTamandi JI. Gn. Soputan, PadangSambianKelod ini, antaralain :

a. Pemanfaatan jalan lingkungan sebagai tempat parkir kendaraan (pagi-malam) 


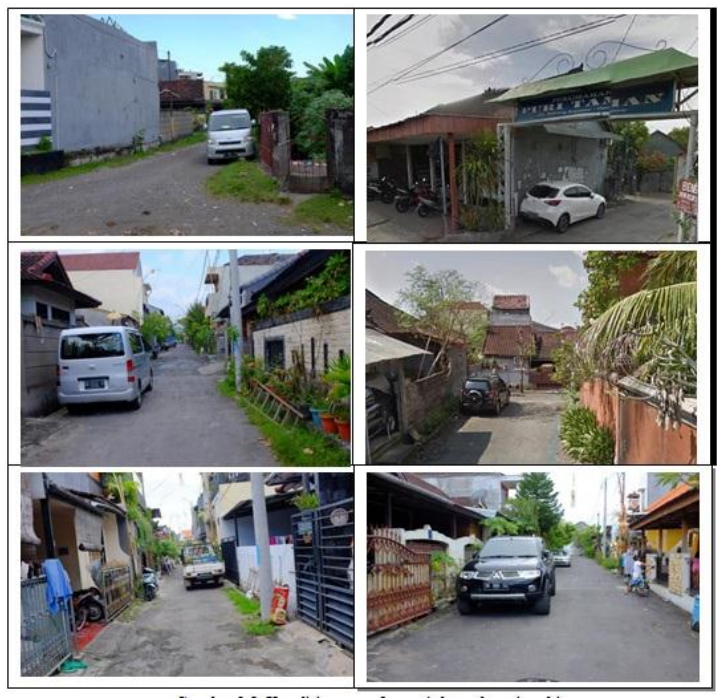

Berdasarkan analisis yang terjadi dalam pemanfaatan jalan lingkungan sebagai tempat parkir ini terlihat jumlah penggunaaan jam yang terjadi yaitu dari pagi hingga malam yaitu dihitung berjumlah 13 jam per hari dan rata-rata terjadi tiap hari hal ini dikarenakan karena banyak tidak memiliki garase sendiri di rumahnya.

\begin{tabular}{|c|c|}
\hline waktu & Hari \\
\hline Dari pagi-malam $(10.00-23.00)=13 \mathrm{jam}$ & Setiap hari (senin-minggu) $=7$ hari \\
\hline
\end{tabular}

b. Pemanfaatan jalan lingkungan sebagai tempat menjemur pakaian (pagi-siang)

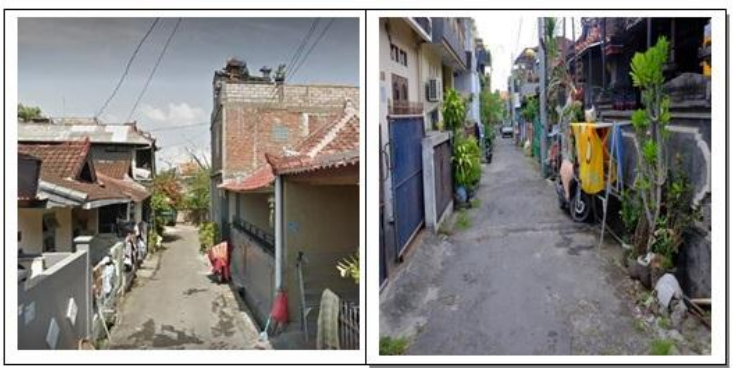

Berdasarkan analisis yang terjadi dalam pemanfaatan jalan lingkungan sebagai tempat menjemur pakaian ini terlihat jumlah penggunaaan jam yang terjadi yaitu dari pagi hingga siang yaitu dihitung berjumlah 6 jam per hari dan rata-rata terjadi tiap hari hal ini dikarenakan karena penghuni yang tidak memiliki lahan di halaman rumah sebagai tempatmenjemur pakaian.

\begin{tabular}{|c|c|}
\hline waktu & Hari \\
\hline Dari pagi-siang $(10.00-16.00)=6$ jam & Setiap hari (senin-minggu) $=7$ hari \\
\hline
\end{tabular}

c. Pemanfaatan jalan lingkungan sebagai tempat menaruh kandang ayam (pagisiang)

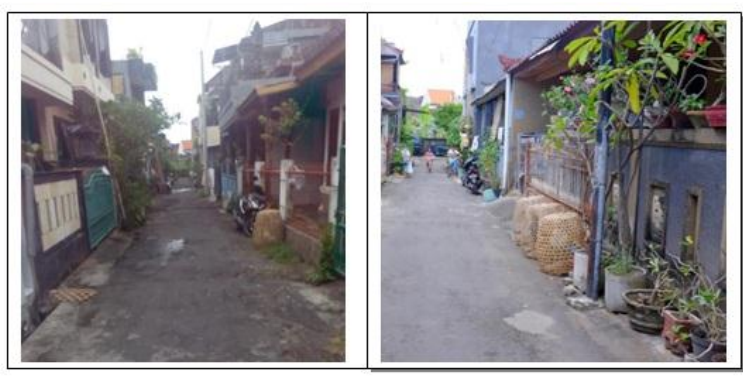

Berdasarkan analisis yang terjadi dalam pemanfaatan jalan lingkungan sebagai tempat kandang ayam ini terlihat jumlah penggunaaan jam yang terjadi yaitu dari pagi hingga siang yaitu dihitung berjumlah 6 jam per hari dan rata-rata terjadi tiap hari hal ini dikarenakan karena penghuni yang tidak memiliki lahan di halaman rumah sebagai tempat menaru

kandang ayam peliharaanya.

\begin{tabular}{|c|c|}
\hline waktu & Hari \\
\hline Dari pagi-siang $(10.00-16.00)=6 j$ am & Setiap hari (senin-minggu $)=7$ hari \\
\hline
\end{tabular}

\section{Analisis Pemanfaatan Ruang (Fungsi)}

Analisis pemanfaatan ruang publik sesuai dengan fungsinya di Perumahan Puri Taman di Jl. Gn. Soputan, Padang Sambian Kelod ini, antara lain :

a. BalaiBanjar,LapanganSerbaGuna, Tempat
Penyewaan Parkir

Berdasarkan analisis terhadap pemanfaatan fungsi pada ruang publik pada Balai banjar, Lapangan olahraga, lahan kosong sebagai tempat parkir dan Tempat penyewaan parkir 
adalah sudah sesuai dengan fungsinya dan tidak terjadi permasalahan di ruang publik pada gambar diatas, namun hal lain terjadi pada pemanfaatan fungsi yang terjadi pada jalan lingkungan, yang banyak terjadi pelanggaran.
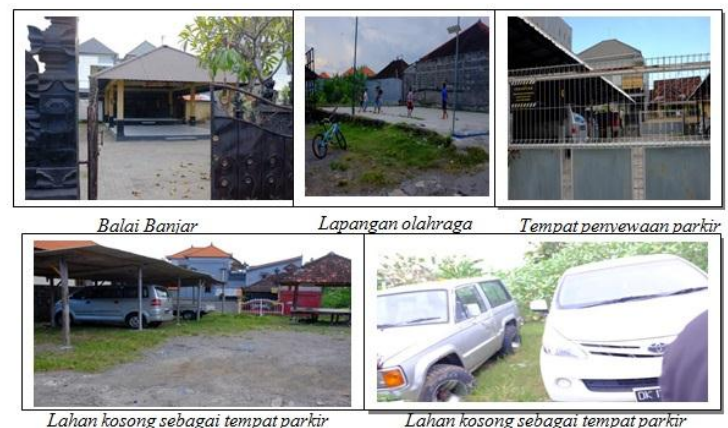

b. Pemanfaatan jalan lingkungan sebagai tempat parkir kendaraan (pagi-malam)

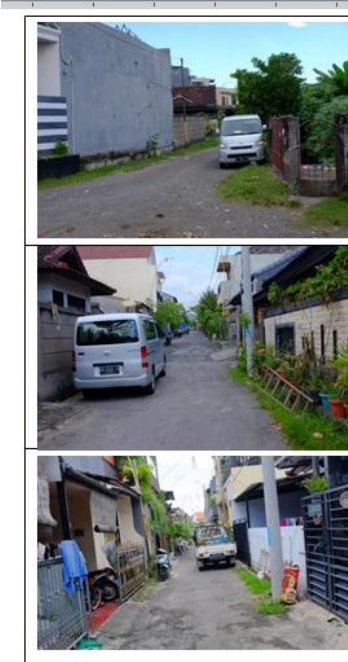

Berdasarkan

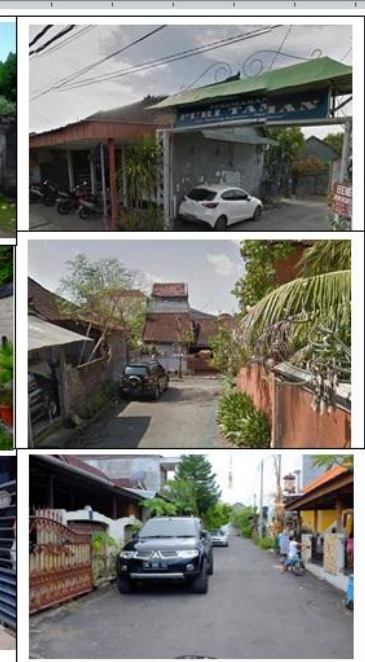

analisis terhadap

pemanfaatan fungsi pada ruang jalan lingkungan perumahan ini, yaitu terdapat banyak kendaraan roda empat maupun roda dua yang memarkirkan di bahu jalan lingkungan padahal mereka tahu bahwa ratarata lebar jalan di perumahan ini yaitu 3 meter sehingga jika ada mobil yang parkir di jalan lingkungan akan menyebabkan sirkulasi jalan lingkungan akan tersendat apalagi jika kendaraan tersebut memarkirkan kendaraan pada titik-titik yang tidak seharusnya seperti di antara tikungan jalan atau pertemuan jalan Ingkungan.

Berdasarkan analisis saya penyebab banyak penghuni perumahan parkir kendaraan di jalan lingkungan karena tidak memiliki garasi kendaraan, karena memiliki kendaraan roda empat lebih dari satu karena rata-rata kapasitas garasi pribadi tiap rumah di perumahan ini hanya cukup untuk 1 mobil, karena jumlah penghuni rumahnya lebih dari 1 kk sehingga cenderung memiliki kendaraan mobil tambahan, dan karena ada tamu yang menginap di salah satau rumah di perumahan ini. Sedangkan untuk kendaraan mtor juga hampir sama namun untuk parkir kendaraan motor masih bisa diatasi dan jumlah sedikit .

\section{c. Pemanfaatan jalan lingkungan sebagai tempat menjemur pakaian (pagi-siang)}

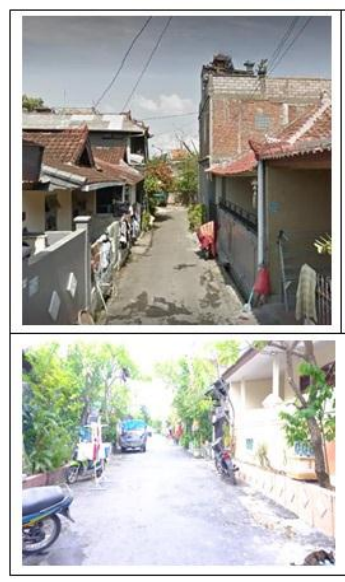

Berdasarkan

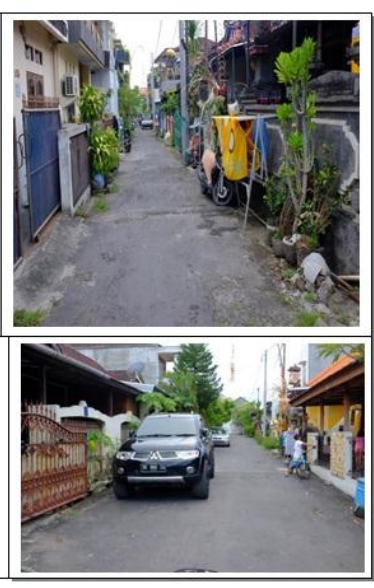

analisis terhadap pemanfaatan fungsi lainnya pada ruang jalan lingkungan perumahan ini, yaitu terdapat penghuni yang menjemur pakaian di jalan lingkungan perumahan, mereka yang rata-rata menjemur pakaiannya berada di depan rumahnya padahal secara kasat mata posisi tempat menaruh jemuran pakaiannya tidak menganggu jalan lingkungan namun dari segi arsitektur akan mengurangi estetika pada pemandangan lingkungan perumahan dan pemanfaatan zonasi ruang publik yang digunakan sebagai ruangprivat.

Berdasarkan analisis saya penyebab banyak penghuni perumahan yang menjemur pakaian di jalan lingkungan karena tidak memiliki lahan di rumahnya sebagai tempat menjemur pakaian, tidak adanya sinar matahari yang dapat masuk ke area rumah karena tertutupi karpot atau habis digunakan sebagai areal bangunan. 
d. Pemanfaatan jalan lingkungan sebagai tempat menaruh kandang ayam (pagi-siang)

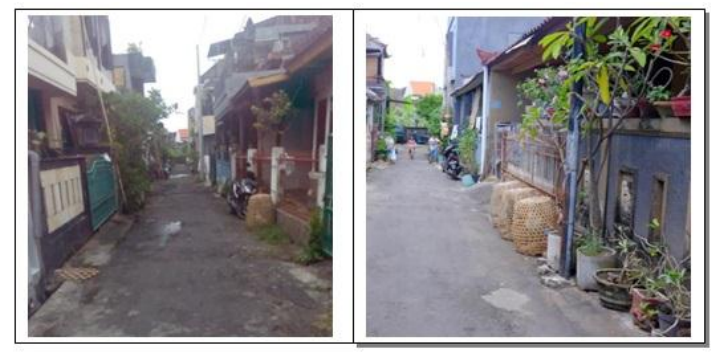

Berdasarkan analisis terhadap pemanfaatan fungsi lainnya pada ruang jalan lingkungan perumahan ini, yaitu terdapat penghuni yang menaruh kandang ayam peliharaannya di jalan lingkungan perumahan, mereka yang rata-rata menaruh kandang ayam peliharaanya berada di depan rumahnya padahal secara kasat mata posisi tempat menaruh jemuran pakaiannya tidak menganggu jalan lingkungan namun dari segi arsitektur akan mengurangi estetika pada pemandangan lingkungan perumahan dan pemanfaatan zonasi ruang publik yang digunakan sebagai ruang privat. Untuk pemanfaatan jalan lingkungan sebagai tempat menaruh kandang ayam peliharaan rata-rata berada di Blok A, dan B karena dengan lebar jalan pada jalan lingkungan Blok $A$ hanya 2 meter dan kondisi rumah yang tidak memiliki ruang terbuka yang cukup umumnya pemanfaatan jalan sebagai tempat menaruh kandang ayam peliharaan juga digunakan sebagai tempat menjemur pakaian karena terbatasnya lahan terbuka di rumah dan juga banyak yang melakukan plat beton pada saluran got agar dapat digunakan sebagai tempat menjemur pakaian dan tempat kandangnayam peliharaan dan agar terkesan tidak menganggu aksebilitas rumah namun itu tidak patut dikarenak jika saluran got tersumbatakan menyulitkan dalam melakukan pengontrolan terhadap saluran got.

\section{KESIMPULAN}

Pemanfaatan ruang publik yang digunakan sebagai area private pada lingkungan perumahan kota, berdasarkan hasil analisis perilaku masyarakat disebabkan karena faktor (a) terbatasnya lahan rumah hal ini merupakan akibat dari pelanggaran sempdan bangunan sehingga seluruh lahan rumah digunakan sebagai area terbangun sesuai ketentuan $\mathrm{kdb}$ yaitu $60 \%$ area terbangun $40 \%$ area terbuka (b) melanggar ketentuan batas sempadan depan hal ini sangat berpengaruh terhadap pemanfaatan jalan sebgai area private karena sesuai ketentuan sempadan depan bangunan yaitu setengah dari ukuran jalan di depan sebagai sempadan bangunan namun dalam pengaplikasiannya seluruh area rumah digunakan area terbangun (c) tidak adanya area terbuka di rumah hal ini masih terbatasnya lahan rumah dan sempadan bangunan karena kebanyakan lingkungan rumah tidak memiliki halaman sehinga jika ingin menjemur atau memilki peliharaan ayam akan menggunakan jalan didepan rumah sebagai area private untuk menjemur pakaian dan menaruh kandang ayam (d) ketidaksesuaian terbatasnya lahan rumah terhadap kebutuhan pribadi seperti rumah yang dimiliki hanya cukup untuk kendaraan 1 mobil dan 2 motor namun pemiliknya memiliki 2 mobil dan 4 motor sehingga mereka harus menggunakan jalan depan rumah sebagai tempat parkir kendaraan .

\section{DAFTAR PUSTAKA}

Carr, Stephen, Mark Franchis, Leane G. Rivlin \& Andrew M. Stone. (1992). Public Space, Press Syn-dicate of University of Cambridge : Melbourne.

Rondinelli, 1985. Perumahan dan Permukiman.Surabaya : ITS. Silas, Johan

Undang -Undang No 4 Tahun 1992 tentang Perumahan dan Pemukiman

Zhang dan Lawson. (2009). 'Meeting and greeting: activities in public outdoor spaces outside highdensity urban residential communities', Journal of Urban design international, vol 14 , no. 4 , h. 207-214 